\title{
LITERATURE REVIEW: THE IMPLEMENTATION OF E-HEALTH AT PRIMARY HEALTHCARE CENTERS IN SURABAYA CITY
}

\author{
Tinjaun Pustaka: Implementasi E-Health di Puskesmas di Kota Surabaya
}

*Yesica Aprillia Putri Adian', Wasis Budiarto'

${ }^{1}$ Department of Health Administration and Policy, Faculty of Public Health, Airlangga University, Indonesia ${ }^{\star}$ Correspondence: yesica.aprillia.putri-2016@fkm.unair.ac.id

\begin{abstract}
Background: The increasing number of patient visits in primary healthcare centers in Surabaya causes long duration of queue in a registration counter. To solve this problem, Surabaya Government has created an online registration system in each health service provider. The e-health is expected to give a positive impact on reducing the queue traffic at the registration counter.

Aim: This study identified whether the online registration system or e-health which has been implemented by primary healthcare centers in Surabaya City is successful or not.

Method: This study was a literature review which collected articles from Google Scholar databases published from 2015 until 2019. Fourteen articles were collected, but only 6 articles were discussed because of their relevant topics.

Results: The review shows that e-health can simplify the process of patient registration and reduce patients' waiting time for health service delivery. The success indicators of e-health program include its well-established system, effective information system, and excellent service for community. Obstacles found in the e-health implementation involve lack of thorough socialization of e-health. In turn, the community prefers a manual registration to e-health.

Conclusion: The e-health service in primary healthcare centers in Surabaya City gives a positive effect on giving a fast and easy process in the registration procedure. However, there are still obstacles in implementing e-health due to lack of socialization.
\end{abstract}

Keywords : queue, e-health, queuing time, primary healthcare centers.

\section{ABSTRAK}

Latar Belakang: Peningkatan jumlah kunjungan pasien yang memanfaatkan pelayanan kesehatan di Puskesmas Kota Surabaya mengakibatkan antrean panjang di loket pendaftaran. Oleh karena itu, Kota Surabaya menciptakan sistem pendaftaran online di Puskesmas dengan harapan bahwa e-health akan memberikan dampak positif pada penurunan volume antrean di loket pendaftaran.

Tujuan: Studi ini bertujuan untuk mengetahui seberapa besar keberhasilan sistem pendaftaran online atau ehealth yang sudah diterapkan di Puskesmas Kota Surabaya.

Metode: Studi ini merupakan literature review. Artikel diambil dari database Google Scholar yang dipublikasikan pada tahun 2015 sampai 2019. Artikel yang diperoleh sebanyak 14 artikel, tetapi hanya 6 artikel memiliki topik yang relevan.

Hasil: Hasil tinjauan pustaka ini menunjukkan bahwa e-health dapat mempermudah proses pendaftaran pasien dan mengurangi waktu tunggu pasien untuk mendapatkan pelayanan. Indikator keberhasilan program e-health meliputi sistem yang baik, sistem informasi yang efektif, dan pelayanan prima bagi masyarakat. Kendala yang ditemukan dalam penerapan e-health adalah sosialisasi yang tidak merata. Akibatnya, masyarakat lebih memilih menggunakan registrasi manual daripada e-health.

Kesimpulan: Adanya layanan e-health di Puskesmas Kota Surabaya dapat memberikan dampak positif dalam mempermudah dan mempercepat proses pelayanan di Puskesmas. Namun, masih terdapat kendala dalam penerapan e-health yang disebabkan oleh kurangnya sosialisasi.

Kata Kunci : antrean, e-health, waktu tunggu, Puskesmas. 


\section{INTRODUCTION}

In the era of industrial revolution 4.0, the development at any sectors has been seen and the globalization has given rise to rapid changes in the order of life and behavior of the people and the behavior of government officials. Changes that occur in the community then lead to the realization of improved government services with a better work system. The influence of globalization is colored by the rapid development of information technology that has led to a new revolution, namely the transition from conventional work systems to the digital. In government institutions, this change is marked by the abandonment of traditional governance which is identical to paperbased administration towards electronic government (e-government). The development of e-government is one of the government's efforts to improve the quality of public services effectively and efficiently in various public sectors. One of them is the increasingly sophisticated technology which probes to fill the expectation of every job or any other needs. A company or organization also expects technology to give accurate information fast. For this reason, technology has an important role in human life (Manurung, 2019).

Nowadays, understanding the reasons beyond the user acceptance or rejection of technology has become one of the most important concerns in the information technology sector (Momani and Jamous, 2017). Technology acceptance is about how people accept technology for use. Acceptance can be further described as a critical factor in determining the success or failure of technology so that understanding technology acceptance is important (Samaradiwakara and Gunawardena, 2014).
The development of technology is there for a health sector, especially health service facilities, such as primary healthcare centers and hospitals. Health service facilities have many problems. For instance, they have convoluted administration procedures, long queue traffic, inaccurate and incomplate patient data, unclear information, etc (Avinda and Handoko, 2017). As a result, the government needs to understand more about people's needs by giving the best services.

Based on the Regulation of Indonesian Ministry of Health No. 75 of 2014, a primary healthcare center is the first level of health service facility by prioritizing promotive and preventive actions to achieve pervasive public health in its working areas. A primary healthcare center must provide fast, appropriate, and best service according to patient's needs.

An increase in patient visits in the primary healthcare centers of Surabaya causes long queue in the registration counter. A queue is the moment when people are waiting to get a treatment or service (Ginting and Rahardjo, 2014). Long queue makes patients wait for a long time and waste their time to get a registration number. Because of this, Surabaya Government created an online registration system in the primary healthcare centers. The online registration system can ease people to register medical check up.

The online registration system is called Electronic Health or e-health. Ehealth is an information technology and communication service application which connecting supporting sectors in health (Sambuaga, Rindengan and Sambul, 2017). The e-health aims to enhance accessibility, efficiency, effectiveness, clinical quality process, and organizational business (Saharuddin, 2017). In the Regulation of Indonesian Ministry of Health No. 36 of 2009 about Health, 
organizing an effective and efficient health service needs health information which can be accessed through an information system. E-health is one of the alternatives to overcome long queue and increase efficiency of registering patients' referral letter.

The Surabaya Health District Office along with the Population and Civil Registry Office collaborate to create ehealth system that can be integrated with the registration system and patients' data in the primary healthcare centers of Surabaya (Setianto, 2016). The integrated e-health system can simplify the administrative process. Moreover, the Surabaya Health District Office partnered with the Communication and Informatics Office to facilitate internet network for accelerating the use of e-health. E-health applications can be downloaded on Play Store (Android user) or App Store (Apple user) as well as www.ehealth.surabaya.go.id.

The Surabaya Government provides an e-health menu on e-kios machine which is available in every primary healthcare center of Surabaya (Agastya and Fanida, 2016). The e-health in Surabaya has been implemented in 63 primary healthcare center and two district government hospitals, including dr. M. Soewandhie District Public Hospital and Bhakti Dharma Husada District Public Hospital. The existence of the online registration system or e-health there is expected to cut short waiting time in the registration counter. For this reason, this literature review discussed only the implementation of e-health in primary healthcare centers of Surabaya.

\section{METHOD}

This present study was a literature review discussing e-health. E-health is still a new innovation in health sector, thus articles that discuss e-health are limited.
Google Scholar was chosen as the database for being subscribed by various open access journals. This study applied a qualitative approach by elaborating results descriptively. It utilized database from articles published from 2015 until 2019 on Google Scholar. Keywords used were "ehealth Surabaya" and "Puskesmas" (primary healthcare centers) which are relevant to the topic of this study. This literature review on e-health and primary healthcare centers analyzed how successful e-health for an online patient registration in primary healthcare centers to reduce long queues at a registration counter and to advance the process of health services in primary healthcare centers. Based on the database and keywords, 14 articles were obtained, but only 6 articles had relevant topics. The results of the literature review were then explained in tables.

\section{RESULTS AND DISCUSSION}

At the beginning, the e-health was tested in ten primary healthcare centers of Surabaya. Those primary healthcare centers located in Ketabang Kali, Rungkut, Jagir, Kali Kedinding, Kedurus, Manukan Kulon, Peneleh, Pucangsewu, Simomulyo, and Dupak must have the International Organization for Standardization or ISO. So that the primary healthcare centers can be referred online to the dr. $M$. Soewandhie District Public Hospital and Bhakti Dharma Husada District Public Hospital. During the implementation of ehealth, they often found some difficulties, such as the competence of human resources, organization's readiness, and organization's work culture. The supervision and evaluation of e-health were conducted over and over again to ensure that it works well. As the e-health runs properly, it has been implemented in 63 primary healthcare centers (100\%). Ehealth as an internet-based service 
systems and applications not only eliminate long queues, but referrals for patients are faster. By e-health, the patient does not need to bring all unnecessary files. They just need to bring their identity card. For the primary healthcare centers no longer need to ask the patient's name and identity because everything is connected through the management information system of primary healthcare centers. Table 1 explains the implementation of e-health in the primary healthcare centers of Surabaya.

\section{E-Health as an Innovation for Registering Patients Online}

In Table 1, the implementation of ehealth was found in recent years. Before e-health was implemented, patient registration was noted manually. Data and medical history were input to the management information system of primary healthcare centers offline. Afterwards, the management information system of primary healthcare centers is integrated with data from the Population and Civil Registry Office, including personal identity (ID) number, personal data, address, and family members in Surabaya. Local citizens of Surabaya can register on e-health by inputting their ID Number, and automatically all their details are in the system. Whereas, patients who are not from Surabaya can register themselves by inputting ID Number and personal data manually.

E-health innovates in several aspects, including the service process, service method, policy, and system (Hafizh, 2016). E-health improves service by updating its process from manual entry to automatic entry. For example, a queue number and medical referral letter registration can be accessed online now. Moreover, e-health is useful for shortening patients' waiting time. With e-health, patients do not need to come to a primary healthcare centers to get a queue number.
Regarding its influence on policy, e-health reforms a new vision, mission, purpose, and strategy as it addresses the real problems of health services in primary healthcare centers. In addition, e-health becomes a bridging point between Surabaya Government as the initiator of ehealth, Surabaya District Health Office, Population and Civil Registry Office, and also Communication and Informatics Office.

Innovation has some levels according to its impacts which may happen during its implementation (Hafizh, 2016). Innovation is a way to introduce new ideas, new product, new service, and new kind of beneficial procedures (Saharuddin, 2017). It aims to upgrade the quality of products, services, and procedures. E-health becomes an innovation for providing better infrastructures in supporting the organizational activity and process. The levels of innovation involve incremental, radical, and transformative innovation. First, an incremental innovation gives a small or rare impact on organization's service or structure. The second level is radical innovation as a basic innovation that needs political support, thus is rarely used. Meanwhile, transformative innovation brings a big change in organization's structure and takes a longer time to achieve the expected results. Ehealth in the primary healthcare centers is on the incremental level because it only gives a small impact. E-health only gives two impacts on the process of patient registration and medical referral letter registration which have been accessed online and integrated with management information system of primary healthcare centers for more accessible patient data and patients' medical history.

E-health is a solution to the problem of patient queue traffic on each workday in primary healthcare centers. During this time patients have to queue for a long 
time, before the start of working hours at the primary healthcare centers. Through ehealth, patients no longer need to bother waiting in line too early at the primary healthcare centers. By e-health, patients can register at a primary healthcare centers and can come for treatment according to the hours listed in queue numbers. This is more efficient for who have limited access to health and its information (Hafizh, 2016). E-health uses a humanist approach. The e-health application has three languages to communicate with patients who use text and audio services, namely Indonesian, Javanese, and Madurese. The choice of three languages is motivated not only because the population of Surabaya City is inhabited by Javanese and Madurese, but also to bring the e-health application closer to the population (Amah, 2016).

Innovation can be sustainable or discontinued (Hafizh, 2016). The e-health initiatied by the Surabaya Government is categorized into a sustainable innovation, giving an on-going change in the current service of patient registration and medical referral letter registration. E-health can make this process done online with a computerized system.

The main output expected from the online patient registration according to patients' perspective is a decrease in queue traffic at the registration counter. Also, it may increase the speed of health services. From health workers' perspectives, e-health is expected to reduce workloads and retrieve computerized patient data so that health workers accomplish lighter and easier works.

\section{Diffusion of E-Health}

Diffusion is an adapting process or innovation process as going through a media at a certain time. It occurs as an innovation creates and offers a newer, better, or more affordable product or service than the current one (Putri, 2016). Diffusion goes in some steps, such as researching information, introducing an innovation, persuading the community to use it, making decision to accept or reject an innovation, and implementing it. Once these steps have been done, the diffusion of innovation is successful.

E-health diffusion was created due to the large number of manual patient registration, thus e-health is required (Putri, 2016). By using e-health, patients have certain time for health service delivery without queing any more (Agastya and Fanida, 2016).

The diffusion of e-health can be done by distributing brochures and leaflets about getting a queue number with ehealth to staffs and patients. Although ehealth diffusion innovations have been carried out, not all primary healthcare centers have an efficient queue because not all patients use the e-health. This is due to an insufficient understanding of information and communication technology, unavailable internet network, and limited media are some reasons beyond this problem. Unfair socialization of e-health also contributes to on-going long queue. Another influential factor on the use of e-health is behavioral intention (Venkatesh, Thong and Xu, 2012). The effect of behavioral intention on technology use will decrease or increase along with the experience of technology use. The experience of technology use can measure user satisfaction with technology (Doll et al., 2004). A decrease in technology use is caused by unsatisfied users, and vise versa.

\section{E-Health as a New Public Service}

Public service which exists as a new paradigm emphasizes the government's role to serve people pervasively (Yusfadhiyah, 2018). Public service is the basic service which can apply, implement, and also serve the community (Khotimah, 
Muchsin and Pindahanto, 2019). The given service is expected to satisfy the community. A new public service prioritizes not only citizens but also customers, seeks for public needs, values community welfare over bussiness profits, as well as find strategies and fairness.

E-health as a new public service applies to all levels of society. E-health for health services in primary healthcare centers counts as a means of speeding up queuing process and predicting disease patterns through observation on frequently accessed health services (Jaliyanti, 2018). The identified disease pattern informs the description of diseases in a region, thus it contributes to more effective disease prevention program. In the long term, it will give an impact on reducing the amount of morbidity in a certain region.

E-health as a public service gives good communication not only to customers but also community since it can be accessed in many areas in Surabaya. It can also identify the public needs as the users expect e-health developed (Yusfadhiyah, 2016). In addition, e-health prioritizes community welfare over bussiness profits as it is expected to assist people with difficulties of accessing ehealth. Implementing e-health in health facilitites acquires the government to find strategies and project the right target, for example conducting socialization about ehealth to patients.

The accountability of e-health is not simple, thus e-health serves rather than steers. In addition, it values not only people but also productivity (Yusfadhiyah, 2018). In this case, the government plays a role to serve community needs rather than control them in using e-health. Ehealth becomes an alternative to enhance productivity by giving easy access to health service and building an independent community.

Above all, staffs in primary healthcare centers should be ready to assist patients when facing troubles in ehealth. Human factor becomes the most determining factor in succeeding the implementation of a new public service (Yusfadhiyah, 2018). The implementation of e-health is also monitored and evaluated to give a better service and to improve staff's work performance. Along with this way, the primary healthcare centers conduct training for their staffs to easily understand the use of e-health.

As previously explained, e-health is also used for online medical referral letter registration. The online system of medical referral letter registration has been connected to the health guarantor, for instance Social Security Agency for Health and hospital partners. Patients who have no health guarantor still uses manual medical referral letter registration. Because of e-health, people are expected to be more independent in utilizing technology and understanding its needs.

\section{The Success of E-Health Service}

A successful program has a good system, effective information system, and excellent services to people. In this section, whether e-health service has successfully been implemented in primary healthcare centers of Surabaya is presented.

\section{Characteristics of a Good System}

A good system is seen from some characteristics, for instance being flexible, easy to utilize, systematic, functional, simple, and efficient for using resources (Jaliyanti, 2018). Based on the implementation of e-health service in recent years, the e-health has fulfilled good characteristics of information system. In terms of flexibility, the e-health service uses database programs, including DBL SQL Server and Java Application. Those database programs are the best ones since many companies and organization have used the same programs (Memon et 
al., 2018). E-health is also considered can increase the staff's work performance at the primary healthcare center because it is easy to adapt and systematic in the implementation flow. Furthermore, it can decrease the duration of queue from 5 minutes to 2 minutes (Jaliyanti, 2018). Ehealth can be accessed through personal android phone, computer, and also e-kios machine in the primary healthcare centers. With its spread in many paltforms, everyone can access it easily.

\section{Excellent Service}

Excellent service is a service with a high-quality standard which follows the development of customer's needs consistently and accurately (Sumolang, Tumbel and Mandagie, 2019). The excellent service is apparent from staffs' ability and attitude, appearance, attention, action, and accountability as a principles of excellent service (Firdaus and Meirinawati, 2019). Staffs are expected to serve with excellence. It is not limited to serving in accordance with patient expectations but is able to serve beyond patient and her or his family expectations (Syafitri et al., 2019).

To support human resources in operating e-health, the primary healthcare centers of Surabaya provide training to their staffs. Moreover, they demand their staffs to politely respond patients' suggestion and criticism as well as show the best physical appearance. As they want to be open to suggestions, they provide a suggestion box where patients may give their opinion of online registration system (Jaliyanti, 2018).

Furthermore, the primary healthcare centers promote the e-health through brochures and leaflets illustrating the ehealth service procedures. All of articles discussed have stated that some obstacles in implementing e-health include lack of promotion and lack of e-kios provided in primary healthcare centers.

\section{Successful Elements of E-Government Project}

Many factors can affect program success. Research shows that leadership quality and effective communication play an important role in project success (Fayaz, Kamal and Amin, 2017). Predevelopment activities are also required during project implementation because they can reduce the failure project rates, especially in information technology systems (Hamada, Mazen and Hassanein, 2011). E-government project in health sector is manifested in the form of e-health as an online registration system. Based on the articles discussed that the successful elements of e-government project such as e-health are political environment, leadership of the head of the e-health and the expert staff, planning, stakeholders, transparancy or visibility, budget, technology, and innovation (Marshela, 2017).

\section{Political Environment}

A political environment is a public situation in which a project is planned in the forms of TDP (Top-Down Project) or BUP (Bottom-Up Project). The primary healthcare centers have TDP-oriented policy which gain support from the executive government. This TDP-oriented policy aims to create a sequent administration and efficient governmental affairs. It is noticable that the e-health is fully funded by Surabaya District Health Office allocating the District Government Budget. Moreover, TDP-oriented policy expedites patient registration and the reporting procedures to Surabaya District Health Office. The implementation of ehealth in the primary healthcare centers is also supported by the Regulation of Indonesian Ministry of Health No. 46 of 2014 about Health Information System, that Health Information System is a set sequence that includes data, information, 
indicators, procedures, devices, technology and resources human beings who are interrelated and managed in a way integrated into direct or action useful decisions in support health development. Another study stated that a political environment has a significant influence on project success, such as the success of ehealth. In this case, a political environment possesses an effective management role (Mark and Nwaiwu, 2015).

\section{Leadership}

Leadership influences the implementation of a program since leaders have a great authority and responsibility for the program. Leadership quality plays an important role in program success (Fayaz, Kamal and Amin, 2017). The implementation of e-health involves some experts of information and communication technology who have good leadership skills. Those experts are in charge to monitor if there are some troubles in the internet network. While, the heads of primary healthcare centers do not directly contribute to the implementation of $e$ health service since the e-health is closely related to the experts of technology and communication who manage the process thorougly (Marshela, 2017).

\section{Planning}

Planning is the first stage in implementing a program. In the first implementation of e-health, the primary healthcare centers of Surabaya had made some plans to find some ways of introducing e-health to the staffs and community. They have shown good planning stage. The good planning stage is shown by the training and socialization activity for all the staffs to introduce ehealth to people, and thus they can use the facility easily (Marshela, 2017). The Surabaya Government has also conducted trials in 10 primary healthcare centers to find out the influence of e-health on healthcare service process. If a mismatch of expectations and reality occurs, improvements can be made (Hamada, Mazen and Hassanein, 2011).

\section{Stakeholders}

Stakeholders can be a factor driving sustainable technology (Singh et al., 2019). Stakeholders can encourage people to use new technology, such as ehealth. As the main stakeholders in the implementation of e-health, Surabaya District Health Office, Population and Civil Registry Office, and Communication and Informatics Office collaborate with the experts of information and technology in every primary healthcare center. The related stakeholders have a high commitment to communicate and cooperate among the staffs and community (Agastya and Fanida, 2016).

\section{Technology}

Technology is the basic asset for digital era. In implementing e-health, technology has been proved to have a good quality because it is designed with database DB2 SQL Server and Java Application which are categorized as the best database program for companies and organization (Memon et al., 2018). Some of the primary healthcare centers in Surabaya also provide computers to access e-health from website and a printer to print out a queue number (Agastya and Fanida, 2016; Marshela, 2017). Thus, using e-health informs patients queue numbers for nursing room. 
Table 1. Implementation of E-Health in Primary Healthcare Centers of Surabaya.

\begin{tabular}{|c|c|c|c|}
\hline Authors & Aims & Methods & Results \\
\hline $\begin{array}{l}\text { Dwi } \\
\text { Jaliyanti, } \\
2018\end{array}$ & $\begin{array}{l}\text { To describe the } \\
\text { implementation } \\
\text { of e-health in } \\
\text { Peneleh Primary } \\
\text { Healthcare } \\
\text { Center, Genteng } \\
\text { Sub-District, } \\
\text { Surabaya. }\end{array}$ & $\begin{array}{l}\text { Method: A descriptive method with } \\
\text { qualitative approach. } \\
\text { - Location: Peneleh Primary Healthcare } \\
\text { Center. } \\
\text { - Respondents: } 10 \text { staffs in Peneleh } \\
\text { Primary Healthcare Center. } \\
\text { - Techniques of data collection: a } \\
\text { standardized interview, observation, } \\
\text { and documentation to search required } \\
\text { data from related sources. } \\
\text { - Validity test: triangulation technique } \\
\text { (for all instruments). }\end{array}$ & $\begin{array}{l}\text { E-health has a good system. } \\
\text { 1. Designed by using database program DBL SQL Server } \\
\text { and Java Application. } \\
\text { 2. Excellent skills of the staffs in operating e-health. } \\
\text { 3. E-health supporting the function of management process } \\
\text { in primary healthcare centers. } \\
\text { 4. Able to decrease long duration of queue in the } \\
\text { registration counter. } \\
\text { 5. Accessible on mobile phone, computer, and e-kios } \\
\text { machine, fastening the process of registration service. } \\
\text { 6. Encouraging knowledge transfer to patients. } \\
\text { E-health has an effectivity information system. } \\
\text { 1. Equipped with data security features for recovery data. } \\
\text { 2. Shortening queuing time to be } 2 \text { minutes. } \\
\text { 3. Able to detect a disease as early as possible which may } \\
\text { have potentials to outbreak. } \\
\text { 4. Providing reports as an output which is required for a } \\
\text { variety of administrative activities to Surabaya District } \\
\text { Health Office. } \\
\text { 5. Offering easy access to health services. } \\
\text { E-health can implement excellent services. } \\
\text { 1. A good operational skill of the staffs after getting training } \\
\text { of e-health procedures. } \\
\text { 2. All staffs respecting patients. } \\
\text { 3. Neat and polite staffs in serving patients. } \\
\text { 4. Providing a suggestion box to identify patients' needs } \\
\text { and expectation. } \\
\text { 5. Un-well implemented e-health without socialization to }\end{array}$ \\
\hline
\end{tabular}




\begin{tabular}{|c|c|c|c|}
\hline Authors & Aims & Methods & Results \\
\hline & & & $\begin{array}{l}\text { community. } \\
\text { 6. Stand-by operators for assisting patients in using e- } \\
\text { health. }\end{array}$ \\
\hline $\begin{array}{l}\text { Dwi Putri } \\
\text { Marshela, } \\
2017\end{array}$ & $\begin{array}{l}\text { To describe the } \\
\text { implementation } \\
\text { of e-health } \\
\text { service in Ngagel } \\
\text { Rejo Primary } \\
\text { Healthcare } \\
\text { Center, } \\
\text { Surabaya. }\end{array}$ & $\begin{array}{l}\text { Method: A descriptive method with } \\
\text { qualitative approach. } \\
\text { - } \quad \text { Location: Ngagel Rejo Primary } \\
\text { Healthcare Center. } \\
\text { - } \quad \text { Technique of data collection: interview, } \\
\text { observation, and documentation to } \\
\text { require get data. } \\
\text { - } \quad \text { Respondents: party responsible (staffs } \\
\text { in Ngagel Rejo Primary Healthcare } \\
\text { Center) for the e-health service and } \\
\text { the users (patients). } \\
\text { Validity test: triangulation techniques } \\
\text { to increase the level of trust for all } \\
\text { instruments. }\end{array}$ & $\begin{array}{l}\text { Key success of e-health. } \\
\text { 1. Has Top-Down Project (TDP) policy. } \\
\text { 2. Involving experts of information and communication } \\
\text { technology. } \\
\text { 3. Conducting a training for all staffs. } \\
\text { 4. Cooperation between Population and Civil Registry } \\
\text { Office and Communication, Informatics Office and } \\
\text { experts of information and communication technology in } \\
\text { every primary healthcare center. } \\
\text { 5. Conducting socialization of e-health use to patients. } \\
\text { 6. Allocating funding from Surabaya District Government } \\
\text { Budget. } \\
\text { 7. Providing e-kios machine, a computer, and a printer to } \\
\text { fasten services in primary healthcare centers. } \\
\text { 8. Conducting socialization of e-health to community. }\end{array}$ \\
\hline $\begin{array}{l}\text { Delza Abdul } \\
\text { Hafizh, } 2016\end{array}$ & $\begin{array}{l}\text { To describe the } \\
\text { implementation } \\
\text { of e-health } \\
\text { service to } \\
\text { upgrade the } \\
\text { quality of health } \\
\text { service in } \\
\text { Pucangsewu } \\
\text { Primary } \\
\text { Healthcare } \\
\text { Center. }\end{array}$ & $\begin{array}{l}\text { Method: A descriptive method with } \\
\text { qualitative approach. } \\
\text { - } \quad \text { Location: Pucangsewu Primary } \\
\text { Healthcare Center. } \\
\text { - } \quad \text { Respondents: staffs in Pucangsewu } \\
\text { Primary Healthcare Center selected by } \\
\text { using purposive sampling } \\
\text { - } \quad \text { Techniques of data collection: } \\
\text { interview and documentation to search } \\
\text { required data. } \\
\text { - Techniques of data analysis: data } \\
\text { reduction, data presentation, and }\end{array}$ & $\begin{array}{l}\text { Innovation typology, level, and category of e-health } \\
\text { implementation. } \\
\text { 1. Innovation for service process in which patients who } \\
\text { were used to taking a queue number and registering } \\
\text { medical referral letter manually can accesse them online } \\
\text { now. } \\
\text { 2. Innovation for service method which reduces patients' } \\
\text { waiting time to get a queue number and medical referral } \\
\text { letter which can be registered directly to a referral } \\
\text { hospital. } \\
\text { 3. Innovation for policy which is under the Surabaya } \\
\text { Government as the initiator. }\end{array}$ \\
\hline
\end{tabular}




\begin{tabular}{|c|c|c|c|}
\hline Authors & Aims & Methods & Results \\
\hline & & $\begin{array}{l}\text { conclusion. } \\
\text { Validity test: triangulation technique to } \\
\text { validity the results of research, just like } \\
\text { comparing observational data with } \\
\text { interview data, then with related } \\
\text { documents. }\end{array}$ & $\begin{array}{l}\text { 4. Innovative system where management information } \\
\text { system of primary healthcare centers has been } \\
\text { integrated into e-health service. } \\
\text { 5. Being on the incremental level because e-health only } \\
\text { gives a small impact on patient registration and medical } \\
\text { referral. } \\
\text { 6. Being a sustainable innovation because e-health gives a } \\
\text { change and retain the running service and system. }\end{array}$ \\
\hline $\begin{array}{l}\text { Nur Sa'idah } \\
\text { Yusfadhiyah, } \\
2018\end{array}$ & $\begin{array}{l}\text { To explore the } \\
\text { implementation } \\
\text { of e-health as a } \\
\text { new public } \\
\text { service in } \\
\text { primary } \\
\text { healthcare } \\
\text { centers in all } \\
\text { primary } \\
\text { healthcare } \\
\text { centers of } \\
\text { Surabaya City. }\end{array}$ & $\begin{array}{l}\text { Method: A descriptive method with } \\
\text { qualitative approach. } \\
\text { - } \quad \text { Location: All Primary Healthcare } \\
\text { Centers of Surabaya City (63 Primary } \\
\text { Healthcare Centers). } \\
\text { - } \quad \text { Respondents: staff in Primary } \\
\text { Healthcare Centers of Surabaya City } \\
\text { chosen by purposive sampling. } \\
\text { - Technique of data collection: in-depth } \\
\text { interviews, observation, and } \\
\text { documentation. } \\
\text { Technique of data analysis: data } \\
\text { reduction, data presentation, and } \\
\text { conclusion. } \\
\text { Validity test: triangulation technique to } \\
\text { eliminate and compare differences in } \\
\text { respondents views during the data } \\
\text { collection process. }\end{array}$ & $\begin{array}{l}\text { E-health as a new public service. } \\
\text { 1. Accessible in many areas in Surabaya. } \\
\text { 2. Slowly but surely, high adaptability of patients in using e- } \\
\text { health. } \\
\text { 3. Stand-by staffs needed to help patients in using e-health. } \\
\text { 4. Conducting socializationof e-health repetitivelyto } \\
\text { encourage patients obey the rules. } \\
\text { 5. Staffs following the operational procedures of services to } \\
\text { increase patients' attention in using e-health. } \\
\text { 6. As much as } 71.49 \% \text { of Customer Satisfaction Index } \\
\text { (CSI) meaning that the services can satisfy patients. } \\
\text { 7. Easy access to health services, such as easy way for } \\
\text { registration. }\end{array}$ \\
\hline $\begin{array}{l}\text { Krishnawan } \\
\text { Panji } \\
\text { Agastya, } \\
\text { Eva Hany }\end{array}$ & $\begin{array}{l}\text { To identify the } \\
\text { implementation } \\
\text { of e-health } \\
\text { service in Jagir }\end{array}$ & $\begin{array}{l}\text { Method: A descriptive method with } \\
\text { qualitative approach. } \\
\text { - Location: Jagir Primary Healthcare } \\
\quad \text { Center. }\end{array}$ & $\begin{array}{l}\text { The success of e-health implementation. } \\
\text { 1. Supported by the Regulation of the Government No. } 46 \\
\text { of } 2014 \text { about Health Information System. } \\
\text { 2. Patient database management in the e-health system }\end{array}$ \\
\hline
\end{tabular}




\begin{tabular}{|c|c|c|c|}
\hline Authors & Aims & Methods & Results \\
\hline $\begin{array}{l}\text { Fanida, } \\
2016\end{array}$ & $\begin{array}{l}\text { Primary } \\
\text { Healthcare } \\
\text { Center, } \\
\text { Wonokromo } \\
\text { Sub-District, } \\
\text { Surabaya. }\end{array}$ & $\begin{array}{l}\text { Respondents: staffs in Jagir Primary } \\
\text { Healthcare Center chosen by using } \\
\text { purposive sampling. } \\
\text { - Instruments: } 8 \text { successful elements of } \\
\text { e-government project. } \\
\text { - } \quad \text { Techniques of data collection: In-depth } \\
\text { interviews, observation, and } \\
\text { documentation. } \\
\text { - Techniques of data analysis: data } \\
\text { reduction, data presentation, and } \\
\text { conclusion. } \\
\text { Validity test: triangulation technique } \\
\text { toward respondents to compare the } \\
\text { observational data, interview data, and } \\
\text { related documents. }\end{array}$ & $\begin{array}{l}\text { under Surabaya District Health Office. } \\
\text { 3. E-health design using the DB2 SQL Server database } \\
\text { program and Java Application. } \\
\text { 4. Developed by the Surabaya Government in collaboration } \\
\text { with the District Health Office, Population and Civil } \\
\text { Registry Office, and Communication and Informatics } \\
\text { Office. } \\
\text { 5. Being transparent in the implementation of e-health by } \\
\text { using promotion media and suggestion box. } \\
\text { 6. Funded from Surabaya District Government Budget. } \\
\text { 7. Providing E-kios machine, a computer and a printer in } \\
\text { each primary healthcare center. } \\
\text { 8. Socializing e-health by disseminating brochures and } \\
\text { posters. }\end{array}$ \\
\hline $\begin{array}{l}\text { Anggraeni } \\
\text { Savira Putri, } \\
2016\end{array}$ & $\begin{array}{l}\text { To describe the } \\
\text { diffusion of e- } \\
\text { health in } \\
\text { Kalijudan } \\
\text { Primary } \\
\text { Healthcare } \\
\text { Center, } \\
\text { Surabaya. }\end{array}$ & $\begin{array}{l}\text { Method: A descriptive method with } \\
\text { qualitative approach. } \\
\text { - } \quad \text { Location: Kalijudan Primary } \\
\text { Healthcare Center. } \\
\text { - } \quad \text { Respondents: patient in Kalijudan } \\
\text { Primary Healthcare Center selected } \\
\text { by using purposive sampling. } \\
\text { - Techniques of data collection: } \\
\text { interview and documentation. } \\
\text { - Techniques of data analysis: data } \\
\text { reduction, data presentation, and } \\
\text { conclusion. }\end{array}$ & $\begin{array}{l}\text { The diffusion process of e-health. } \\
\text { 1. Conducting socialization to patients by distributing } \\
\text { brochures of how to pick a queue number by using e- } \\
\text { health. } \\
\text { 2. Decrease in the duration and traffic of queues in a health } \\
\text { service facility. } \\
\text { 3. Patients lacking capability in using e-health. } \\
\text { 4. Lack of information and communication, internet } \\
\text { network, and media. } \\
\text { 5. The unbalance and unclear socialization to patients } \\
\text { identified as problems. }\end{array}$ \\
\hline
\end{tabular}




\section{Innovation}

E-health has changed manual registration to online registration, thus, making patients easier to access patient registration (Agastya and Fanida, 2016). To support online patient registration, the government can create another innovation, for instance conducting training for health staffs and practical socialization to patients in using e-health service from e-kios machine, website, or android mobile application (Putri, 2016; Marshela, 2017; Sa'idah, 2017).

\section{The Benefit of E-Health System}

Based on the articles discussed, there are some benefits of e-health system. First, e-health system is facilitating services for patients in the Surabaya City by only carrying identity number (Hafizh, 2016). Second, e-health system speeds up the patient referral system and improve the quality of patient services based on the patient's medical resume referred (Hafizh, 2016). Third, ehealth system is facilitating access to patient registration and reducing time in the primary healthcare centers (Putri, 2016). Fourth, e-health system reduces data entry requirements for primary healthcare center staffs (Yusfadhiyah, 2018).

\section{Monitoring and Evaluation System of E- Health Implementation}

A monitoring system is the process of observing and tracking system at run time. It is the basis of control operations and corrective actions for running systems (Alhamazani et al., 2015). Meanwhile, an evaluation system is a part of the management system and the process of determining the effectiveness of performing and implementing the system (Tetiana et al., 2018). The monitoring and evaluation is carried out by the system by the Surabaya District Health Office through an application dashboard that monitors the number of online referrals, ten most diseases, types of patient payments, polyclinics most visited, how many health workers serve people, and registration of monitoring real time at the primary healthcare centers.

\section{The Impact of E-Health Implementation}

The gap in information and technology capability that still occurs in Surabaya City people and internet network traffic that is busy with limited bandwidth during peak hours, can be overcome by providing free internet training to the public through the Broadband Learning Center (BLC) which is spread throughout in all district offices (Putri, 2016). In addition, by alerting officers at the district offices to help people who experience difficulties when interacting with e-health. Provides free wifi in all pulbic places so people can use it to learn the internet. Meanwhile, heavy internet network traffic, especially during peak hours, can be overcome.

The positive impact that can be taken is the people's trust in health services in the Surabaya City to be positive so that with a positive mindset the people will be able to help the government by contributing ideas, thoughts, and energy towards ideal health services for Surabaya City. In addition, through this initiative, an overview of the Surabaya population health database can be obtained, which later the data can be integrated with other data (Marshela, 2017).

For the long impact, the presence of integrated data potentially can develop a disease prevention and health maintenance program. This program will be based on frequently accessed health services which gather as disease patterns seen in e-health system (Agastya and Fanida, 2016). The expected outcome of the programs is a decrease in morbidity 
and an increase in the levels of public health to create healthy communities.

\section{CONCLUSION}

E-health is considered successful when it can implement a good system, become an effective information system, and provide excellent services. The output of an online patient registration system is a decrease in queue traffic and shorten its duration. As a result, patients do not have to wait long for queue number to receive desired health service. E-health is also give a positive effect in medical referral letter. E-health is integrated with a management information system of primary healthcare center as staffs will be easier to report and monitor early diagnosis. Therefore, it can help disease prevention success and health maintenance program. The expected outcome of the program is a decrease in morbidity and an increase in the levels of public health to create healthy communities. However, there are some shortcomings in the implementation of ehealth in primary healthcare centers. One of them is the unbalanced socialization of the e-health to patients. Therefore, some people still face difficulties in operating ehealth, turning out to register themselves manually. Training health staffs is required, and thus they are able to operate the e-health service and transfer their knowledge to patients.

\section{CONFLICT OF INTEREST}

The authors state that there is no conflict of interest for this article.

\section{REFERENCES}

Agastya, K. P. and Fanida, E. H. (2016) 'Penerapan Layanan E-Health di Puskesmas Jagir Kelurahan Jagir Kecamatan Wonokromo Kota
Surabaya', Jurnal Fakultas IImu Sosial dan Hukum, 1(1), pp. 1-10.

Alhamazani, K. et al. (2015) 'An overview of the commercial cloud monitoring tools: research dimensions, design issues, and state-of-the-art', Computing, 97(4), pp. 357-377. doi: 10.1007/s00607-014-0398-5.

Amah, N. M. (2016) 'Penerapan Layanan Electronic Health (E-Health) Di Puskesmas Kota Surabaya', Publika, 4(10), pp. 1-10.

Avinda, A. and Handoko, R. (2017) 'Efektivitas E-Health Di Rumah Sakit Umum Daerah Dr. M. Soewandhie Surabaya', JPAP: Jurnal Penelitian Administrasi Publik, 3(1), pp. 592599. doi: 10.30996/jpap.v3i1.1227.

Doll, W. J. et al. (2004) 'The meaning and measurement of user satisfaction: A multigroup invariance analysis of the end-user computing satisfaction instrument', Journal of Management Information Systems, 21(1), pp. 227-262. doi: 10.1080/07421222.2004.11045789.

Fayaz, A., Kamal, Y. and Amin, S. U. (2017) 'Critical Success Factors in Information Technology Projects', Management Science Letter, 7, pp. 73-80. doi: 10.5267/j.msl.2016.11.012.

Firdaus, F. and Meirinawati (2019) 'Pelayanan Prima Melalui Program Instagram (Instalasi Gawat Darurat Modern) Di Rumah Sakit Umum Daerah Dr. Iskak Kabupaten Tulungagung', Publika, 7(5), pp. 1-7. Ginting, P. L. and Rahardjo (2014) 'Analisis Sistem Antrian dan Optimalisasi LayananTeller (Studi Kasus pada Bank $X$ di Kota Semarang)', Jurnal Studi Manajemen \& Organisasi, 11(1), pp. 58-66. doi: 10.14710/jsmo.v11i1.13162.

Hafizh, D. A. (2016) 'Inovasi Pelayanan 
Publik Studi Deskriptif tentang Penerapan Layanan e-Health dalam meningkatkan Kualitas Pelayanan Kesehatan di Puskesmas Pucangsewu Kota Surabaya', Kebijakan dan Manajemen Publik, 4(3), pp. 1-9.

Hamada, M. A., Mazen, S. A. and Hassanein, E. E. (2011) 'The Role of the Pre-development Activities in Information Systems Projects' Failure', in 46th Annual Conference on Statistics, Computer Science, and Operations Research. Egypt: 46th Annual Conference on Statistics, Computer Science, and Operations Research, pp. 1-116.

Jaliyanti, D. (2018) 'Puskesmas Peneleh Kecamatan Genteng Kota Surabaya', Jurnal Administrasi Perkantoran, 6(2), pp. 26-34.

Khotimah, K., Muchsin, S. and Pindahanto, R. (2019) 'Pelayanan Publik Berbasis Online dalam Pembuatan Kartu AK / 1 ( Antar Kerja ) menggunakan Sistim Hellowork Pasuruan.', Jurnal Respon Publik, 13(5), pp. 89-95.

Manurung, I. H. G. (2019) 'Sistem Informasi Lembaga Kursus Dan Pelatihan (LKP) City Com Berbasis Web Menggunakan PHP Dan MYSQL', Jurnal Mahajana Informasi, 4(1), pp. 42-50.

Mark, J. and Nwaiwu, J. N. (2015) 'Impact of Political Environment on Business Performance of Multinational Companies in Nigeria', African Research Review, 9(3), pp. 1-10. doi: 10.4314/afrrev.v9i3.1.

Marshela, D. P. (2017) Implementasi Layanan e-health di Puskesmas Ngagel Rejo Kota Surabaya dalam Memberikan Pelayanan Kepada Masyarakat, Repository Universitas Airlangga. Surabaya.

Memon, S. et al. (2018) 'Performance comparison of QEC network based JAVA application and web based PHP application', International Journal of Advanced Computer Science and Applications, 9(8), pp. 555-564. doi: 10.14569/ijacsa.2018.090870.

Momani, A. M. and Jamous, M. M. (2017) 'The Evolution of Technology Acceptance Theories', International Journal of Contemporary Computer Research (IJCCR), 1(1), pp. 51-58. doi: 10.1002/anie.201003816.

Putri, A. S. (2016) Difusi Inovasi Program E-Health Di Puskesmas Kalijudan Surabaya, Repository Universitas Airlangga. Surabaya.

Sa'idah, N. (2017) 'Analisis Penggunaan Sistem Pendaftaran Online (EHealth) Berdasarkan Unified Theory Of Accepptance And Use Of Technology (UTAUT)', Jurnal Administrasi Kesehatan Indonesia, 5(1), pp. 72-81.

Saharuddin, E. (2017) 'Inovasi Implementasi E-Health sebagai Manifestasi Smart City di Kota Yogyakarta untuk Meningkatkan Kualitas Pelayanan Kesehatan Ibu dan Anak', Jurnal Kajian IImu Administrasi Negara, 5(1), pp. 1-14.

Samaradiwakara and Gunawardena (2014) 'Comparison of Existing Technology Acceptance Theories and Models to Suggest A Well Improved Theory/Model', International Technical Sciences Journal, 1(1), pp. 21-36. Available at:

file:///C:/Users/Toni/Documents/Citav i.

Sambuaga, J. H., Rindengan, Y. D. Y. and Sambul, A. M. (2017) 'Perancangan E-health Kota Cerdas ( Studi Kasus : Kota Manado )', Jurnal Teknik Informatika, 11(1), pp. 1-8. doi: https://doi.org/10.35793/jti.11.1.2017 
.16920 .

Schnackenberg, A. K. and Tomlinson, E. C. (2016) 'Organizational Transparency: A New Perspective on Managing Trust in OrganizationStakeholder Relationships', Journal of Management, 42(7), pp. 17841810.

doi: $10.1177 / 0149206314525202$.

Setianto, W. A. (2016) 'Inovasi e-Health Dinas Kesehatan Kota Surabaya', Jurnal IImu Komunikasi, 14(3), pp. 151-164.

Singh, A. et al. (2019) 'Stakeholder Role for Developing A Conceptual Framework of Sustainability in Organization', Sustainability (Switzerland), 11(1), pp. 1-16. doi: 10.3390/su11010208.

Sumolang, I. E., Tumbel, A. L. and Mandagie, Y. (2019) 'Analysis Of The Effect Of Prima Service and Complete Products on the Purchase Decision of Products in Matahari Manado Tows Square', Jurnal Riset Ekonomi, Manajemen, Bisnis, dan Akuntansi, 7(8), pp. 3359-3368.

Syafitri, E. M. et al. (2019) 'Character Education Based-on Local Wisdom in Excellent Service Course', in Advances in Social Science, Education and Humanities Research. Bali: Atalantis Press, pp. 365-368.

Tetiana, H. et al. (2018) 'Innovative model of enterprises personnel incentives evaluation', Academy of Strategic Management Journal, 17(3), pp. 16.

Venkatesh, V., Thong, J. Y. L. and Xu, X. (2012) 'Consumer Acceptance and Use of Information Technology: Extending The Unified Theory', Management Information Systems Research Center, 36(1), pp. 157178.

Yusfadhiyah, N. S. (2018) 'Pelaksanaan
E-Health Pada Puskesmas di Kota Surabaya dilihat dari Perspektif New Public Service', Kebijakan dan Manajemen Publik, 6(3), pp. 1-9. 